\title{
PERSEPSI DAN SIKAP MASYARAKAT TERHADAP AKTIVITAS PABRIK SMELTER DI DESA MOROSI KECAMATAN MOROSI KABUPATEN KONAWE
}

\author{
Sukmawati Abdullah ${ }^{1}$ \\ Yani Taufik ${ }^{2}$ \\ Rizal Sahyono
}

\begin{abstract}
ABSTRAK
Persepsi dan sikap masyarakat terhadap aktivitas pabrik smelter di Desa Morosi Kecamatan Morosi Kabupaten Konawe. Persepsi dalam penelitian ini merupakan cara pandang masyarakat terhadap aktivitas pabrik smelter. Penelitian ini melihat persepsi dan sikap terhadap perubahan pendapatan, kesempatan kerja dan peluang usaha. Tujuan dalam penelitian ini adalah untuk mengetahui bagaimana persepsi dan sikap masyarakat terhadap dampak aktivitas ekonomi yang ditimbulkan oleh pabrik smelter di Desa Morosi Kecamatan Morosi Kabupaten Konawe. Populasi dalam penelitian ini adalah 97 Kepala Keluarga (KK), Penentuan sampel dilakukan dengan cara Simpel Random Sampling, sehingga sampel dalam penelitian bejumlah 49 responden. Hasil penelitian ini menunjukan bahwa persepsi dan sikap masyarakat terhadap dampak keberadaan pabrik smelter terhadap pendapatan, kesempatan kerja dan peluang usaha dominan berada pada kategori netral. Artinya, masyarakat menganggap bahwa aktivitas pabrik smelter di Desa Morosi tidak memiliki pengaruh yang signifikan terhadap perekonomian masyarakat setempat.
\end{abstract}

Kata kunci: persepsi, sikap, aktivitas pabrik smelter

\section{ABSTRACT}

This study aims to see community perceptions and attitudes towards the activities of smelter factories in Morosi Village, Morosi District, Konawe District. Perception in this research is the community's perspective on smelter factory activities. This study looks at perceptions and attitudes towards changes in income, employment opportunities, and business opportunities. The purpose of this study is to find out how the perceptions and attitudes of the community towards the impact of economic activities caused by smelter factories in Morosi Village, Morosi District, Konawe District. The population in this study is 97 heads of households. Determination of the sample is done by simple random sampling, so the sample in the study is 49 respondents. The results of this study indicate that people's perceptions and attitudes towards the impact of the existence of smelter factories on income, employment opportunities, and dominant business opportunities are in the neutral category. That is, the community considers that the activity of the smelter factory in Morosi Village does not have a significant influence on the economy of the local community.

Keywords: perception, attitude, smelter factory activities

\footnotetext{
${ }^{1}$ Jurusan Penyuluhan Pertanian, Fakultas Pertanian, Universitas Halu Oleo, Pos-el: sukmawatiabdullah@ymail.com

2 Jurusan Penyuluhan Pertanian, Fakultas Pertanian, Universitas Halu Oleo

${ }^{3}$ Jurusan Agribisnis Fakultas Pertanian Kendari 93232, South-east Sulawesi, Indonesia
} 


\section{A. PENDAHULUAN}

Pada era desentralisasi saat ini, pemberian wewenang dari pemerintah pusat kepada pemerintah daerah dalam pengelolaan sumber daya alam memberikan dampak yang sangat berbeda dibandingkan di era sentralisasi. Pemerintah daerah yang memiliki kekuasaan untuk memanfaatkan segala potensi sumber daya alam di daerah, pemerintah daerah dapat memberikan izin kepada pihak swasta atau industri yang bergerak di bidang pertambangan untuk mengelola dan memanfaatkan sumber daya alam (mineral). Usaha pertambangan di Indonesia tersebar di seluruh wilayah di tanah air dan obyek penambangannya berbeda-beda misalnya pertambangan minyak bumi, batu bara, emas, biji besi, bauksit dan nikel serta jenis tambang lainnya. Kegiatan pertambangan berhubungan langsung dengan dampak ekonomi selain itu ber-implikasi pu-la pada strategi bertahan hidup masyarakat sekitar pertambangan tersebut (Kartodi-hardjo, dkk., 2005).

Pergantian Kabinet Indonesia Bersatu (KIB) II ke Kabinet Kerja, para pemilik industri pertambangan berharap pemerintah bisa memberikan perhatian lebih pada sektor minyak dan gas bumi yang pada saat ini pada keadaan yang kritis. Salah satu bentuk perhatian pemerintah yaitu dengan memastikan pembangunan pabrik pengolahan dan pemurnian (smelter) mineral milik perusahaan tambang berjalan dengan baik. Smelter ini merupakan fasilitas pengolahan hasil tambang yang berfungsi untuk meningkatkan kandungan hasil tambang. Aktivitas pabrik smelter atau perusahaan tidak dapat dipungkiri memiliki dampak terhadap masyarakat sekitarnya dan lingkungan. Pertambangan merupakan salah satu sumber daya alam potensial yang dapat dimanfaatkan sebagai sumber devisa untuk pembangunan nasional, serta dapat menjadi salah satu penopang sumber ekonomi suatu Negara. Potensi yang kaya akan sumber daya alam akan dapat menumbuhkan terbukanya perusahaan-perusahaan untuk melakukan eksplorasi pertambangan sumber daya tersebut (Herman, dan Danny Z. 2005).

Melalui UU Minerba No. 4 tahun 2009 tentang pertambangan mineral dan batubara, pemerintah memberlakukan agar perusahaan tambang segera membangun smelter karena di tahun 2014 akan diberlakukan pelarangan ekspor mineral mentah. Dengan adanya UU Minerba Minerba No. 4 tahun 2009, perusahaan didorong untuk membangun smelter sehingga semua barang tambang harus diolah dulu baru boleh di ekspor. Pada Pasal 102 UU minerba No. 4 tahun 2009, Pemegang IUP dan IUPK wajib meningkatkan nilai tambah sumberdaya mineral dan/atau batu bara dalam pelaksanaan penambangan, pengolahan dan pemurnian, serta pemanfaatan mineral dan batu bara. Kewajiban ini mulai berlaku pada tahun 2014. UU Minerba tersebut dilengkapi dengann Peraturan Menteri ESDM (PERMEN) No. 7 tahun 2012 yang disempurnakan menjadi Permen No. 11 tahun 2012. Peraturan itu berinti (pasal 21), perusahaan tambang yang me-ngantongi izin IUP dan IUPR dilarang keras untuk menjual mineral mentah ke luar negeri dalam jangka waktu 3 bulan setelah berlakunya Permen ini (Permen ini di tetapkan bulan Februari).

Pembangunan wilayah salah satunya adalah pembangunan di bidang ekonomi. Pembangunan ekonomi adalah suatu proses yang menyebabkan pendapatan per kapita penduduk suatu masyarakat meningkat da-lam jangka panjang (Sutrisno dalam Bin-tarto, 1988). Keberadaan perusahaan dapat memberikan dampak ekonomi dan sosial secara langsung maupun tidak lang-sung kepada masyarakat lokal. Beberapa dampak langsung perusahaan adalah kesempatan kerja/lowongan pekerjaan bagi orang setempat, program bantuan dan pembinaan. Dampak tidak langsung dari perusahaan adalah pembukaan jalan dan transportasi perusahaan dapat sekaligus dimanfatkan oleh masyarakat, kebutuhan pekerja perusahaan seperti 
sayuran, daging, ikan, buah-buahan dapat memajukan perekonomian masyarakat setempat. Besar kecilnya dampak tersebut sangat bergantung pada tingkat kepedulian perusahaan dan pekerjanya serta kesiapan sumber daya manusia (SDM) masyarakat lokal dalam memanfaatkan pe-luang yang ada. Selama ini rendahnya SDM masyarakat lokal selalu menjadi masalah utama sehingga mereka selalu tersingkir oleh pendatang dari luar daerah dalam memanfaatkan peluang pekerjaan. Masalah tersebut sebenarnya dapat diatasi dengan menigkatkan pendidikan dan memberikan pelatihan (Raden I, dkk, 2010).

Kabupaten Konawe memiliki Luas wilayah daratan 5.798,94 kilometer persegi (579.894 hektar) merupakan11,65 persen dari total luas daratan Provinsi Sulawesi Tenggara (BPS, 2017). Kecamatan Morosi memiliki luas wilayah $76,49 \mathrm{~km}^{2}$. Wilayah Kecamatan Morosi inilah PT Virtue Dragon Nikel Industry membangunan smelter. Pabrik smelter yang didirikan oleh PT Virtue Dragon Nikel Industry sejak tahun 2012 dengan luas area sekitar $100 \mathrm{Ha}$. Pembangunan smelter ini diharapkan akan membuka peluang kerja dan peluang usaha bagi masyarakat sekitar area pabrik smelter, selanjutnya akan dapat meningkatkan perekonomian masyarakat. Namun hal ini juga dapat membuat pola hidup masyarakat berubah menjadi lebih konsumtif. Hal lain yang merugikan masyarakat misalnya saja kerusakan jalan, terganggunya arus jalan umum oleh kendaraan perusahaan, dan polusi udara. Selain itu, dengan keberadaan perusahaan tambang atau pabrik smelter tersebut tidak dapat dipungkiri akan menimbulkan pertambahan penduduk di suatu daerah. Hal ini diakibatkan karena keberadaan perusahaan tersebut menimbulkan daya tarik masyarakat luar yang datang kedaerah tersebut untuk mencari pekerjaan dan untuk meningkatkan taraf hidup. Persepsi masyarakat lokal terhadap aktivitas/kegiatan pembangunan smelter diduga cukup beragam, hal ini di- sebabkan tidak semua warga masyarakat memperoleh manfaat positif dari keberadaan smelter tersebut.

Aktivitas pabrik smelter di wilayah Kecamatan Morosi Kabupaten Konawe diharapkan dapat memberikan kontribusi sosial ekonomi kepada masyarakat tetapi bukan menerima semua penduduk untuk bekerja di perusahaan, namun secara partisipatif mendorong pertumbuhan ekonomi yang berdampak pada tingkat kesejahteraan masyarakat. Berdasarkan rumusan latar belakang dan di atas maka tujuan dalam penelitian ini adalah untuk mengetahui bagaimana persepsi dan sikap masyarakat terhadap dampak aktivitas ekonomi yang ditimbulkan oleh pabrik smelter di Desa Morosi Kecamatan Morosi Kabupaten Konawe.

Kerangka piker penelitian ini dapat diuraikan bahwa hadirnya perusahaan tambang atau pabrik smelter di Desa Morosi, mengakibatkan perubahan yang signifikan terhadap kehidupan masyarakat desa. Perubahan-perubahan tersebut dapat dilihat dari perubahan kehidupan masyarakat sebelum dan sesudah adanya perusahaan tersebut yang dulunya bermata pencaharian dibidang agraris, namun sekarang masyarakat telah beralih menjadi masyarakat yang bermata pencaharian di bidang industri.

Perubahan aktifitas masyarakat yang paling tampak adalah beralihnya profesi masyarakat petani ke profesi lain yakni dari sektor pertanian kesektor non pertanian. Hal ini pula yang mempengaruhi berbagai aspek di kehidupan masyarakat, sehingga menimbulkan persepsi dan sikap masyarakat terhadap pendapatan, kesempatan kerja dan peluang usaha dengan hadirnya perusahaan atau pabrik smelter tersebut. Oleh karena itu dengan melihat adanya permasalahan tersebut maka perlu adanya suatu kajian mendalam terhadap fenomena yang terjadi diwilayah ini, yakni peneliti akan melihat bagaimana persepsi dan sikap masyarakat terhadap aktivitas pabrik smelter di desa mereka. 


\section{B. METODE PENELITIAN}

Penentuan lokasi penelitian dilakukan secara purposive (sengaja), dengan pertimbangan responden tersebut bermukim di sekitar pabrik. Responden yang dipilih merupakan kepala keluarga di daerah yang berbatasan dengan pabrik smelter (PT. VDNI) dan merasakan dampak yang ditimbulkan oleh pabrik smelter tersebut yaitu Desa Morosi Kecamatan Morosi Kabupaten Konawe. Penelitian ini akan di laksanakan pada bulan Juni 2018 sampai selesai.

Sugiyono (2009) mengemukakan populasi adalah keseluruhan objek yang akan diteliti. Populasi dalam penelitian ini adalah seluruh masyarakat di Desa Morosi Kecamatan Morosi yang berjumlah 97 KK (Kepala Keluarga). Metode pengambilan sampel dilakukan dengan menggunakan metode Simple Random Sampling (Arikunto, S. 2016) yaitu teknik pengambilan sampel dari anggota populasi yang dilakukan secara acak tanpa memperhatikan strata yang ada dalam populasi itu. Berdasarkan pertimbangan tersebut maka dalam penentuan sampel penelitian ini menggunakan rumus Slovin (Sugiyono, 2009) sebagai berikut:

$$
n=\frac{N}{1+N e^{2}}
$$

Keterangan:

$\mathrm{n} \quad=$ ukuran sampel

$\mathrm{N}=$ ukuran populasi

$\mathrm{e}=$ Tingkat kesalahan dalam memilih anggota sampel yang ditolelir (tingkat kesalahan yang diambil dalam sampling ini adalah sebesar $10 \%$ )

$$
\begin{aligned}
& n=\frac{N}{1+N(0,1)^{2}} \\
& n=\frac{97}{1+97(0,1)^{2}} \\
& \mathrm{n}=49,23 .
\end{aligned}
$$

Jadi sampel yang digunakan dalam penelitian ini adalah $49 \mathrm{KK}$
Jenis data dalam penelitian ini adalah data kualitatif dan data kuantitatif.

a. Data kualitatif, yaitu data yang berupa keterangan-keterangan yang dinyata-kan oleh informan-informan dalam in-stansi terkait, seperti mata pencaharian, pendapatan, kesempatan kerja, dan peluang usaha, masyarakat Desa Morosi Kecamatan Morosi terhadap persepsi dan sikap masyarakat terhadap aktifitas pabrik smelter dengan menggunakan kuesioner.

b. Data kuantitaf, yaitu data yang berbentuk angka-angka, seperti: data tentang jumlah penduduk, jumlah kepala keluarga, umur, serta penghasilan masyarakat Desa Morosi Kecamatan Morosi terhadap persepsi dan sikap masyarakat terhadap aktifitas pabrik smelter yang diperoleh melalui observasi dan wawancara.

Data yang digunakan dalam penelitian ini adalah data primer dan data sekunder. Data primer adalah data yang diperoleh secara langsung dari objek yang diteliti melalui wawancara atau pemberian kuesioner pada masyarakat Desa Morosi Kecamatan Morosi. Sumber primer adalah sumber data yang langsung memberikan data kepada peneliti (Sugiyono, 2009).

Data sekunder adalah data yang telah dikumpulkan oleh lembaga pengumpul data dan dipublikasikan kepada masyarakat pengguna seperti Badan Pusat Statistik, Internet, Kantor Kecamatan, Kantor Lurah/Desa setempat dan berbagai media yang ada melalui pencatatan. Secara singkat dapat dikatakan bahwa data sekunder adalah sumber data yang tidak secara langsung memberikan data kepada peneliti, misalnya melalui orang lain atau melalui dokumen (Sugiyono, 2009).

Berdasarkan tujuan penelitian ini untuk menggetahui persepsi dan sikap masyarakat terhadap aktivitas pabrik smelter. Penelitian ini merupakan penelitian deskriptif yang diperoleh kemudian peneliti mengunakan program Microsoft Office 
Excel 20017 untuk menentukan rata-rata, simpangan baku, nilai maksimum, dan nilai minimum data.

\section{HASIL DAN PEMBAHASAN}

\section{Sejarah PT. Virtue Dragon Nickel Industri (VDNI)}

PT. VDNI merupakan salah satu perusahaan yang mendirikan pabrik smelter pada Tahun 2012 dan mulai beroperasi pada Tahun 2016 yang berada di Desa Morosi Kecamatan Morosi Kabupaten Konawe Sulawesi Tenggara yang memiliki luas area pabrik 100 ha. Dimana terdiri dari Pltu, Smelter, Gudang, dan Mes. PT. Virtue Dragon Nikel Industri mempunyai induk perusahaan bernama De Long Nickel., LTD di Jiangsu, China merupakan sebuah perusahaan swasta yang bergerak dibidang peleburan nikel ore menjadi nickel Pig Iron yang beroperasi dalam kawasan industri Konawe di Des Morosi.

Rencana pengembangan dan nilai investasi PT. VDNI di Sulawesi Tenggara di bagi kedalam 3 phase pengembangan. Phase 1 (awal Tahun 2016) memanfaatkan lahan sebesar 100 ha, dengan nilai investasi US\$ 1 billion dan jumlah produksi mencapai 600.000ton pertahun. Pada Phase 2 (pertengahan Tahun 2017) membutuhkan lahan sebanyak $200 \mathrm{Ha}$, dengan nilai investasi US\$ 2 billion dan jumlah produksi mencapai 1.200.000 ton pertahun. Sedangkan untuk Phase 3 (pertengahan Tahun 2018) akan menggunakan lahan sebanyak $200 \mathrm{Ha}$, dengan nilai investasi sebesar US\$ 2 billion dengan kapasitas produksi 1.200.000 ton pertahun. Produk dari PT. VDNi diperuntukkan dan dijual oleh induk PT.VDNi yaitu De long Nickel Co. Ltd.

Kegiatan operasional PT. VDNi, perusahaan membangun pembangkit listrik (PLTU) dengan kapasitas terpasang 2x30 MW, 4x60 MW, dan 2x125 MW dengan perkiraan konsumsi batubara mencapai 15.000 ton perbulan. Legalitas (perijinan) pabrik smelter PT VDNi telah mecapai
$100 \%$ dan beroperasi secara penuh pada tahun 2017.

Tabel 1 menunjukkan sebagian besar penduduk Desa Morosi bermata pencaharian sebagai buruh industri, yaitu sebesar $31,17 \%$. Berdasarkan jumlah penduduk yang sebagian besar bermata pencaharian sebagai buruh industri maka sektor industri dijadikan sebagai mata pencaharian utama penduduk Desa Morosi.

Tabel 1. Jumlah Penduduk Berdasarkan Mata Pencaharian di Desa Morosi Kecamatan Morosi Kabupaten Konawe, Tahun 2018

\begin{tabular}{|c|c|c|c|}
\hline No. & $\begin{array}{l}\text { Jenis Mata } \\
\text { Pencaharian }\end{array}$ & $\begin{array}{c}\text { Jumlah } \\
\text { Penduduk } \\
\text { (Jiwa) }\end{array}$ & $\%$ \\
\hline 1. & Petani & 54 & 13,47 \\
\hline 2. & PNS & 4 & 1,00 \\
\hline 3. & Peternak & 7 & 1,75 \\
\hline 4. & Montir & 4 & 1,00 \\
\hline 5. & Buruh Industri & 116 & 28,93 \\
\hline 6. & Penjahit & 11 & 2,74 \\
\hline 7. & Petani tambak & 12 & 2,99 \\
\hline 8. & Tukang & 4 & 1,00 \\
\hline 9. & Wiaraswasta & 8 & 2,00 \\
\hline 10. & Guru Honor & 9 & 2,24 \\
\hline 11. & $\begin{array}{l}\text { Mengurus } \\
\text { Rumah Tangga }\end{array}$ & 62 & 15,46 \\
\hline 12. & Sopir Mobil & 7 & 1,75 \\
\hline \multirow[t]{2}{*}{13.} & Belum Bekerja & 103 & 25,69 \\
\hline & Jumlah & 401 & 100,00 \\
\hline
\end{tabular}

Sumber: Data Potensi Desa Morosi, 2018

\section{Identitas Responden}

Identitas responden yang termasuk dalam penelitian ini meliputi: umur, tingkat pendidikan, dan pekerjaan. Lebih jelasnya diuraikan sebagai berikut:

\section{a. Umur}

Umur merupakan usia seseorang yang dihitung sejak lahir sampai saat penelitian dilaksanakan. Umur bagi seorang masyarakat tani sangat mempengaruhi kemampuan fisik dalam mengelola suatu usaha atau kegiatan. Umumnya seseorang yang masih berumur muda dan sehat akan mem- 
pengaruhi kemampuan berfikir yang lebih maju, dinamis dan lebih kuat, lebih bersemangat dibandingkan dengan seorang yang usianya lebih tua dimana kemampuan kerja seseorang akan bertambah dan pada suatu tingkatan umur tertentu akan mulai menurun. Menurut Soeharjo dan Patong (1984), bahwa katagori umur produktif adalah mulai dari usia 15-54 tahun dan selebihnya masuk katagori umur non produktif. Untuk lebih jelasnya data disajikan pada Tabel 2.

Tabel 2. Distribusi Responden Berdasarkan Golongan Umur di Desa Morosi Kecamatan Morosi Kabupaten Konawe, Tahun 2018

\begin{tabular}{|c|c|c|c|}
\hline No. & $\begin{array}{c}\text { Golongan Umur } \\
\text { (Tahun) }\end{array}$ & $\begin{array}{c}\text { Jumlah } \\
\text { (Jiwa) }\end{array}$ & $\%$ \\
\hline 1. & Produktif (15 - & 42 & 85,71 \\
\hline \multirow[t]{3}{*}{2.} & 54) & 7 & 14,29 \\
\hline & $\begin{array}{l}\text { Non Produktif } \\
\text { (diatas 54) }\end{array}$ & & \\
\hline & Jumlah & 49 & 100,00 \\
\hline
\end{tabular}

Tabel 2 menunjukan bahwa sebanyak 42 orang responden $(85,71 \%)$ berada pada usia produktif antara 15-54 tahun, sedangkan responden yang berada pada usia non produktif diatas 54 tahun sebanyak 7 orang $(4,84)$. Hal ini berarti bahwa kemampuan fisik dan kemampuan berfikir masyarakat di Desa Morosi masih dalam kondisi produktif. Produktif tidaknya umur seseorang tentunya akan berpengaruh terhadap kemampuan kerja dan cara berfikir. Seseorang yang berumur relatif lebih muda (usia produktif) biasanya akan lebih terampil dan dinamis dalam bertindak bila dibandingkan dengan seseorang yang berada pada usia tidak produktif. Oleh karena itu, masyarakat yang memiliki keterbatasan dalam kemampuan fisik maka seharusnya pihak-pihak yang bersangkutan memberikan lapangan pekerjaaan sesuai dengan kemampuan baik secara fisik ataupun secara psikis. Sehingga dapat diharapkan masyarakat memperoleh penghidupan yang layak dan berkelanjutan.

\section{b. Tingkat Pendidikan}

Tingkat pendidikan yang dimaksud dalam penelitian ini adalah tingkat pendidikan formal yang pernah dilalui responden. Pendidikan merupakan salah satu indikator dalam menentukan pola pikir dan tindakan seseorang. Apabila seseorang memiliki pendidikan yang memadai, maka seseorang tersebut lebih mudah berpikir dan bertindak secara rasional dalam mengambil keputusan dengan memper-timbangkan berbagai aspek yang akan terjadi.

Hasil penelitian ini menunjukan bahwa rata-rata pendidian formal yang dimiliki oleh responden kurang. Untuk lebih jelasnya pendidikan responden ditampilkan pada Tabel 3.

Tabel 3. Keadaan Responden Berdasarkan Tingkat Pendidikan Formal di Desa Morosi Kecamatan Morosi Kabupaten Konawe Tahun 2018.

\begin{tabular}{clcc}
\hline No. & Tingkat Pendidikan & $\begin{array}{c}\text { Jumlah } \\
\text { Responden } \\
\text { (Jiwa) }\end{array}$ & \% \\
\hline 1. & Tidak Sekolah & 1 & 2,04 \\
\hline 2. & Tamat SD/Sederajat & 13 & 26,53 \\
\hline 3. & Tamat SMP/Sederajat & 13 & 26,53 \\
\hline 4. & Tamat SMA/Sederajat & 17 & 34,69 \\
\hline 55. & Universitas/Sederajat & 5 & 10,20 \\
\hline & Jumlah & $\mathbf{4 9}$ & $\mathbf{1 0 0 , 0 0}$ \\
\hline
\end{tabular}

Sumber: Data primer diolah 2018

Tabel 3 menunjukkan bahwa responden di Desa Morosi Kecamatan Morosi pada umumnya telah menempuh pendidikan formal. Jumlah responden yang tidak tamat Sekolah Dasar (SD) sebanyak 1 orang $(2,04 \%)$, lebih sedikit bila disbandingkan dengan responden yang menempuh jenjang pendidikan sekolah dasar (SD) sebanyak 13 orang $(26,53 \%)$. Sedangkan responden yang menempuh jenjang pendidikan Sekolah Menengah Pertama (SMP) sebanyak 13 orang (26,53\%), lebih sedikit bila dibandingkan dengan responden yang menempuh jenjang pendidikan Sekolah Menengah Atas (SMA) sebanyak 17 orang $(34,69 \%)$, serta responden yang menempuh 
jenjang pendidikan tingkat Universitas sebanyak 5 orang $(10,20 \%)$.

Kondisi tingkat pendidikan para responden yang mayoritas berpendidikan tamatan sekolah atas dan sekolah dasar memungkinkan mereka hanya berharap pada pengalaman dalam mengusahakan usaha tani dan aktivitas perekonomian lainnhya, karena semakin tinggi pendidikan formal responden, maka pengetahuan dan wawasannya semakin luas pula serta cara berpikirnya akan semakin rasional. Pendidikan pula merupakan salah satu faktor yang dapat menentukan dan merangsang seseorang untuk kreatif dan inovatif dalam menyelesaikan setiap permasalahan yang berkaitan dengan usaha yang digeluti.

\section{c. Pekerjaan}

Pekerjaan merupakan sumber penghasilan yang ditekuni oleh responden. Pekerjaan menentukkan besar kecilnya pendapatan yang diterima oleh responden. Pekerjaan yang ditekuni oleh masyarakat berbeda-beda, sesuai dengan profesi yang dimiliki oleh masing-masing masyarakat. Dari sampel penelitian yang berjumlah 49 orang responden di Desa Morosi, diketahui ada 13 macam pekerjaan yang dimiliki oleh objek penelitian, yaitu, petani, PNS, wiraswasta, nelayan, karyawan tambang, penambang batu, tukang ojek, buruh bangunan dan pedagang. Penjelasan dapat dilihat pada Tabel 4.

Tabel 4 menunjukkan responden dengan pekerjaan karyawan tambang memiliki jumlah yang sangat banyak yaitu 21 orang $(42,86 \%)$ dibandingkan jenis pekerjaan lain, sebelum adanya aktivitas pabrik smelter di Desa Morombo pada umumnya responden bekerja sebagai petani namun setelah adanya tambang banyak masyarakat yang menjadi karyawan tambang baik tambang yang berada di desanya maupun tambang yang berada di tetangga desa atau kecamatan lain. Jenis pekerjaan responden juga berdampak pada tingkat kesejahteraannya.
Tabel 4. Distribusi Responden Berdasarkan Pekerjaan di Desa Morosi Kecamatan Morosi Kabupaten Konawe Tahun 2018.

\begin{tabular}{rlcc}
\hline No. & \multicolumn{1}{c}{ Pekerjaan } & $\begin{array}{c}\text { Jumlah } \\
\text { (Jiwa) }\end{array}$ & \% \\
\hline 1. & Guru Honor & 1 & 2,04 \\
\hline 2. & Karyawan & & \\
& Tambang & 21 & 42,86 \\
\hline 3. & Kepala Desa & 1 & 2,04 \\
\hline 4. & Montir & 1 & 2,04 \\
\hline 5. & Pedagang & 2 & 4,08 \\
\hline 6. & Pengurus Masjid & 1 & 2,04 \\
\hline 7. & Petani & 10 & 20,41 \\
\hline 8. & Petani Tambak & 3 & 6,12 \\
\hline 9. & PNS & 3 & 6,12 \\
\hline 10. & Sekretaris Desa & 1 & 2,04 \\
\hline 11. & Sopir Mobil & 1 & 2,04 \\
\hline 12. & Tukang & 1 & 2,04 \\
\hline 13. & Wiraswasta & 3 & 6,12 \\
\hline & Jumlah & 49 & 100,00 \\
\hline
\end{tabular}

Sumber: Data diolah tahun 2018

\section{Persepsi Masyarakat Terhadap Aktivitas Pabrik Smelter}

Persepsi yang dimaksud dalam penelitian ini adalah persepsi masyarakat yang berada di sekitar lokasi pabrik smelter dalam hal ini masyarakat Desa Morosi Kecamatan Morosi yang mencakup persepsi masyarakat terhadap keberadaan dan aktivitasnya dalam hubungannya dengan ekonomi masyarakat berdasarkan persepsi terhadap pendapatan, kesempatan kerja dan peluang usaha yang ditimbulkan oleh aktivitas pabrik smelter.

\section{a. Pendapatan}

Pendapatan yang dimaksud adalah sejumlah uang yang diterima oleh responden setelah total penerimaan diku-rangi dengan total pengeluaran (biaya). Pendapatan tersebut digunakan masyarakat dalam hal ini responden untuk melanjut-kan usahanya dan juga dapat digunakan untuk memenuhi kebutuhan hidupnya. Baik pendapatan dari sektor pertanian atau-pun dari sektor lain yang dihitung perbulan. Jumlah pendapatan pendapatan masyarakat di Desa Morosi Kecamatan Morosi sebelum dan 
sesudah adanya pabrik smel-ter dapat dilihat pada Tabel 5 .

Tabel 5. Keadaan Pendapatan Sebelum dan Sesudah Adanya Pabrik Smelter di Desa Morosi Kecamatan Morosi Tahun 2018

\begin{tabular}{lc}
\hline $\begin{array}{c}\text { Dampak Aktivitas Pabrik } \\
\text { Smelter Terhadap } \\
\text { Pendapatan }\end{array}$ & $\begin{array}{c}\text { Pendapatan } \\
\text { Rata-Rata } \\
\text { (Rp/Bulan) }\end{array}$ \\
\hline $\begin{array}{l}\text { Sebelum Adanya Pabrik } \\
\text { Smelter }\end{array}$ & Rp 1.414 .286 \\
\hline $\begin{array}{l}\text { Setelah Adanya Pabrik } \\
\text { Smelter }\end{array}$ & $\mathrm{Rp} 2.374 .490$ \\
\hline
\end{tabular}

Sumber: Data primer diolah 2018

Tabel 5 menunjukkan bahwa pendapatan sebelum adanya kegiatan pertambangan, rata-rata pendapatan masyarakat sebanyak $\mathrm{Rp}$ 1.414.286 untuk setiap bulanya, dengan pendapatan tertinggi sebanyak Rp 6.000.000 dan terendah sebanyak $\mathrm{Rp}$ 500.000. Sedangkan pendapatan ratarata responden setelah adanya kegiatan pertambangan sebanyak Rp 2.374.490 un-tuk setiap bulannya, dengan pendapatan tertinggi sebanyak Rp 5000.000 dan terendah sebanyak Rp 700.000. Namun ada beberapa masyarakat yang jumlah pendapatnya berkurang sejak adanya aktivitas pabrik smelter, hal ini disebabkan karena masyarakat tersebut mengalami penurunan hasil usaha sejak kehadiran pabrik smelter.

Jumlah pendapatan masyarakat desa Morosi setelah adanya pabrik smelter yang berada pada kategori rendah yaitu antara Rp. 2.133.333,32 - Rp. 699.999,99 adalah sebanyak 15 orang $(30,61 \%)$, hal ini dikarenakan walaupun dengan adanya pabrik smelter di Desa Morosi namun tidak merubah status pekerjaan mereka sehingga membuat pendapatan yang mereka peroleh untuk setiap bulannya tidak secara signifikan meningkat. Sedangkan pendapatan masyarakat desa Morosi setelah adanya pabrik smelter yang berada pada kategori sedang yaitu antara Rp. 3.566.666,66 - Rp. 2.133.333,33 adalah sebanyak 27 orang $(55,10 \%)$ dan kategori tinggi yaitu antara Rp. 5.000.000 -
Rp. 3.566.666,67 adalah sebanyak 3 orang $(14,29 \%)$, hal ini dikarenakan pergantian pekerjaan setelah adannya pabrik smelter di Desa Morosi, masyarakat yang sebelumnya hanya meng-andalakan perekonomian pada sektor per-tanian namun setelah adanya pabrik smelter banyak dari masyarakat Desa Morosi men-jadi karyawan pabrik walaupun tidak dipungkiri bahwa beberapa warga mengalami penurunan pasca berope-rasinya pabrik namun hal tersebut tidak berpengaruh secara segnifikan terhadap pendapatan yang mereka terima untuk setiap bulannya. Persepsi pendapatan dalam penelitian ini adalah tanggapan masyarakat terhadap pendapatan yang diperoleh, yaitu banyak-nya jumlah uang yang diterima masyarakat pasca adanya pabrik smelter di Desa Morosi Kecamatan Moros, baik pendapatan dari sektor pertanian ataupun dari sektor lain. Persepsi masyarakat Desa Morosi terhadap aktivitas pabrik smelter yang kaitanya dengan pendapatan dapat dilihat pada Tabel 6.

Tabel 6. Persepsi Masyarakat Terhadap Pendapatan di Desa Morosi Kecamatan Morosi Kabupaten Konawe Tahun 2018

\begin{tabular}{clcc}
\hline No. & $\begin{array}{l}\text { Persepsi } \\
\text { Masyarakat } \\
\text { Terhadap } \\
\text { Pendapatan }\end{array}$ & $\begin{array}{c}\text { Jumlah } \\
\text { Responden } \\
\text { (Jiwa) }\end{array}$ & $\%$ \\
\hline 1. & Positif (>19) & 7 & 14 \\
\hline 2. & Netral (19 $\quad-$ & 35 & 71 \\
\hline 3. & Negatif $(<13)$ & 7 & 14 \\
\hline & Jumlah & $\mathbf{4 9}$ & $\mathbf{1 0 0}$ \\
\hline
\end{tabular}

Sumber: Data Primer Diolah 2018

Tabel 6 menunjukkan bahwa persepsi masyarakat Desa Morosi Kecamatan Morosi terhadap aktivitas pabrik smelter yang kaitannya dengan pendapatan masyarakat yang berada pada kategori negatif sebanyak 7 orang (14\%), hal ini disebabkan karena masyarakat desa Morosi menganggap bahwa dengan kebe-radaan pabrik smelter pendapatan rata-rata masyarakat pendatang lebih tinggi diban-dingkan 
dengan masyarakat lokal setelah pabrik smelter beroprasi. Kemudian kategori netral sebanyak 35 orang $(71 \%)$ sedangkan kategori positif sebanyak 7 orang (14\%), hal ini dikarenakan masya-rakat Desa Morosi menganggap bahwa de-ngan keberadaan pabrik smelter akan membantu petani dalam meningkatkan pen-jualan hasil pertanian, di mana dengan banyaknya pekerja di pabrik smelter atau karyawan maupun masyarakat lokal membeli hasil pertanian yang hasilkan oleh petani lokal. Rata-rata masyarakat setuju bahwa keberadaan pabrik smelter berdam-pak positif pada pendapatan masyarakat sekitar pabrik smelter khususnya masyarakat di Desa Morosi. Hal ini dikarenakan masyarakat menganggap bahwa dengan keberadaan pabrik smelter pendapatan masyarakat meningkat setelah adanya pabrik smelter di bandingkan sebelum adanya pabrik smelter serta dengan keberadaan pabrik smelter dililingkungan masyarakat dapat menigkatkan harga hasil pertanian yang dihasilkan oleh masyarakat baik dari sektor pertanian maupun dari sektor tambak ikan. Hal tersebut dikarenakan makin bertambahnya penduduk di Desa Morosi sehingga menaikkan pula kebutuhan akan hasil pertanian dan perikanan masyarakat sekitar pabrik smelter.

\section{b. Kesempatan Kerja}

Kesempatan kerja adalah jumlah penduduk yang bekerja atau orang yang sudah memperoleh pekerjaan. Kesempatan kerja dalam penelitian ini adalah peluang kerja bagi masyarakat saat operasi dan pasca penambangan. Untuk lebih jelasnya dampak pasca penambangan terhadap kesempatan kerja masyarakat dapat dilihat pada Tabel 7.
Tabel 7. Persepsi Masyarakat Terhadap Kesempatan Kerja di Desa Morosi Kecamatan Morosi Kabupaten Konawe Tahun 2018.

\begin{tabular}{|c|c|c|c|c|}
\hline No. & $\begin{array}{r}\mathbf{P} \\
\mathrm{Ma} \\
\mathrm{Te} \\
\text { Kesem } \\
\end{array}$ & $\begin{array}{l}\text { sepsi } \\
\text { arakat } \\
\text { aadap } \\
\text { tan Kerja }\end{array}$ & $\begin{array}{c}\text { Jumlah } \\
\text { Responden } \\
\text { (Jiwa) }\end{array}$ & $\%$ \\
\hline 1. & Positif & $(>28)$ & 3 & 6 \\
\hline 2. & Netral & $(22-28)$ & 42 & 86 \\
\hline 3. & Negatif & $(<22)$ & 4 & 8 \\
\hline \multicolumn{3}{|c|}{ Jumlah } & 49 & 100 \\
\hline
\end{tabular}

Sumber: Data primer diolah 2018

Tabel 7 menunjukkan bahwa persepsi masyarakat Desa Morosi Kecamatan Morosi terhadap aktivitas pa-brik smelter yang kaitannya dengan kesem-patan kerja yang dimilki oleh masyarakat yang berada pada kategori negatif sebanyak 4 orang (8\%), hal ini dikarenakan ma-syarakat menganggap bahwa setelah ber-oprasinya pabrik smelter tidak melakukan sosialisasi tentang jenis pekerjaan yang tersedia bagi masyarakat serta masyarakat menganggap pula bahwa perusahaan tidak memberikan petatihan kerja pada masyarakat lokal, yaitu masyarakat Desa Morosi. Kemudian kategori netral sebanyak 42 orang (88\%) sedangkan kategori positif sebanyak 3 orang (4\%), hal ini dikarenakan dominan dari masyarakat di Desa Morosi menggapa bahwa dengan beroperasinya pabrik smelter telah menyediakan lapangan kerja baru bagi masyarakat dimana peker-jaan tersebut tidak hanya berorientasi men-jadi karyawan di perusahaan namun membuka berbagai jenis usaha lain sehingga meningkatkan kesempatan kerja bagi masyarakat sekitar perusahaan.

Dalam hal ini rata-rata masyarakat setuju bahwa keberadaan pabrik smelter berdampak positif pada kesempatan kerja masyarakat sekitar pabrik smelter khususnya masyarakat di Desa Morosi. Hal ini dikarenakan masyarakat menganggap bahwa dengan keberadaan pabrik smelter di Desa Morosi menyediakan lapangan kerja baru bagi masyarakat sekitar perusahaan 
khususnya masyarakat di Desa Morosi. Bertambahnya lapangan pekerjaan masyarakat dikarenakan perusahaan memberikan prioritas kepada masyarakat lokal dalam hal ini masyarakat Desa Morosi untuk berkerja di pabrik smelter sehingga dengan keadaan tersebut menumbuhkan kesempatan kerja bagi masyarakat. Dengan terbukanya lapangan pekerjaan bagi masyarakat desa morosi memicu keinginan masyarkat untuk memotivasi setiap anggota keluarganya agar berkerja di pabrik smelter. Adapun langkah-langkah masyarakat yaitu memotivasi anak-anak atau keluarga mereka untuk menuntut ilmu kejenjang pendidikan yang lebih tinggi agar mendapatkan peluang kerja yang lebih besar dalam hal jabatan dalam pekerjaan pada pabrik smelter tersebut di kemudian hari. Sehingga, hal ini tentunya akan berdampak posistif pula pada penambahan penghasilan atau pendapatan masyarakat dalam suatu keluarga. Selain itu, dengan bertambahnya kesempatan kerja akan mengurangi tingkat pengangguran di sekitar tambang, yaitu masyarakat Desa Morosi.

\section{c. Peluang Usaha}

Peluang usaha merupakan keadaan dimana terciptanya lapangan pekerjaan sehingga setiap individu yang mampu bekerja dapat memperoleh pekerjaan yang sesuai dengan keahlian, keterampilan dan bakat yang dimiliki oleh masyarakat. Distribusi besarnya peluang usaha bagi responden dilihat pada Tabel 8 .

Tabel 8. Persepsi Masyarakat Terhadap Peluang Usaha di Desa Morosi Kecamatan Morosi Kabupaten Konawe Tahun 2018.

\begin{tabular}{|c|c|c|c|c|}
\hline No. & $\begin{array}{r}\text { Per } \\
\text { Masy } \\
\text { Terh } \\
\text { Peluan }\end{array}$ & $\begin{array}{l}\text { epsi } \\
\text { rakat } \\
\text { adap } \\
\text { Usaha }\end{array}$ & $\begin{array}{c}\text { Jumlah } \\
\text { Responden } \\
\text { (Jiwa) }\end{array}$ & $\%$ \\
\hline 1. & Positif & $(>15)$ & 5 & 10 \\
\hline 2. & Netral & $(15-9)$ & 41 & 84 \\
\hline 3. & Negatif & $(<9)$ & 3 & 6 \\
\hline \multicolumn{3}{|c|}{ Jumlah } & 49 & 100 \\
\hline
\end{tabular}

Tabel 8 menunjukkan bahwa persepsi masyarakat Desa Morosi Kecamatan Morosi terhadap aktivitas pabrik smelter yang kaitannya dengan peluang usaha yang dimilki oleh masyarakat yang berada pada kategori negatif sebanyak 3 orang (6\%), hal ini dikarenakan sebagian masyarakat menganggap bahwa perusahaan tidak mem-berikan bantuan kepada masyarakat unutk membuka usaha, sehingga masyarakat yang kurang secara ekonomi merasa tidak mudah/sulit untuk merintis usaha baru. Kemudian kategori netral sebanyak 41 orang (84\%) sedangkan kategori positif sebanyak 5 orang (10\%), hal ini disebabkan karena dominan masyarakat menganggap bahwa mata pencaharian masyarakat setelah ada smelter bertambah (tidak lagi hanya sebagai petani).

Rata-rata masyarakat setuju bahwa dengan keberadaan pabrik smelter berdampak positif pada peluang usaha yang dimilki oleh masyarakat sekitar pabrik smelter khususnya masyarakat di Desa Morosi. Hal ini dikarenakan masyarakat menganggap bahwa dengan adanya pabrik smelter Di Desa Morosi mata pencaharian masyarakat menjadi bertambah yaitu, masyarakat tidak lagi hanya berprofesi sebagai petani namun masyarakat bekerja sebagai karyawan pabrik serta membuka usaha-usaha kecil seperti kios-kios kecil dan usaha rumah kos sehingga peluang usaha bertambah banyak dari sebelumnya serta masyarakat menganggap bahwa perusahaan perlu mengadakan kegiatan usaha kecil menengah untuk masyarakat dengan cara memberikan bantuan kepada masyarakat sekitar agar masyarakat dapat menciptakan berbagai jenis usaha mikro di lingkungan mereka atau sekitar perusahaan.

\section{Sikap Masyarakat Terhadap Aktivitas Pabrik Smelter}

Sikap masyarakat setempat terhadap penambangan mangan yang dipengaruhi oleh pengetahuan yang dimiliki oleh masyarakat setempat. Menurut (Azwar, S. 
2009) sikap manusian adalah evaluasi, perasaan, dan kecenderungan dari individu terhadap suatu objek yang relatif konsisten. Sikap menempatkan orang dalam kerangka pemikiran mengenai menyukai atau tidak menyukai sesuatu, mengenai mendekati atau menjauhinya. Sikap masyarakat yang dimaksud dalam penelitian ini adalah sikap masyarakat di Desa Morosi Kecamatan Morosi yang mencakup tiga indikator, yaitu sikap terhadap pendapatan setelah adanya pabrik smelter, kesempatan kerja dan peluang usaha yang dimiliki oleh masyarakat.

\section{a. Pendapatan}

Sikap masyarakat terhadap aktivitas pabrik smelter yang kaitannya dengan pendapatan masyarakat di Desa Morosi Kecamatan Morosi dapat dilihat pada Tabel 9.

Tabel 9. Sikap Masyarakat Terhadap Pendapatan di Desa Morosi Kecamatan Morosi Kabupaten Konawe Tahun 2018.

\begin{tabular}{|c|c|c|c|c|}
\hline \multirow[b]{2}{*}{ No. } & \multicolumn{2}{|c|}{ Sikap Masyarakat } & \multicolumn{2}{|l|}{ Jumlah } \\
\hline & \multicolumn{2}{|c|}{$\begin{array}{l}\text { Terhadap } \\
\text { Pendapatan }\end{array}$} & $\begin{array}{l}\text { Responden } \\
\text { (Jiwa) }\end{array}$ & $\%$ \\
\hline 1. & Tinggi & $(>21)$ & 4 & 8 \\
\hline 2. & Sedang & $(17-21)$ & 44 & 90 \\
\hline 3. & Rendah & $(<17)$ & 1 & 2 \\
\hline Jum & & & 49 & 100 \\
\hline
\end{tabular}

Tabel 9 menunjukkan bahwa sikap masyarakat Desa Morosi Kecamatan Morosi terhadap aktivitas pabrik smelter yang kaitannya dengan pendapatan masyarakat yang berada pada kategori rendah sebanyak 1 orang (2\%), hal ini dikarenakan pabrik smelter masih perlu meningkatkan perekonomian masyarakat sekitar walaupun tidak dipungkiri bahwa dengan adanya pabrik smelter telah meningkatkan semangat masyarakat untuk menjalankan pekerjaan yang di tekuninya. Kemudian kategori sedang sebanyak 44 orang (90\%) sedangkan kategori tinggi sebanyak 4 orang $(8 \%)$, hal di karenakan masyarakat menyikapi keberadaan tambang dengan cara meminimalisir kendala kendala dalam meningkatkan pere- konomiannya sehingga berpengaruh positif terhadap pendapatan yang diperoleh oleh masyarakat.

Rata-rata masyarakat mendukung dan setuju dengan keberadaan pabrik smelter di Desa Morosi Kecamatan Morosi dimana hal ini ditunjukkan dengan sikap masyarakat untuk meningkatkan pendapatnya semenjak kehadiran pabrik smelter di Desa Morosi. Sikap positif masyarakat tersebut dsisebabkan karena, dengan adanya pabrik smelter telah mempengaruhi ekonomi masyarakat dimana keberadaan pabrik smelter telah meningkatkan semangat masyarakat untuk menjalankan pekerjaan baik yang telah ditekuni oleh masyarakat maupun pekerjaan baru sehingga hal ini telah meningkatkan pendapatan masyarakat.

\section{b. Kesempatan Kerja}

Sikap masyarakat terhadap aktivitas pabrik smelter yang kaitannya dengan kesempatan kerja masyarakat di Desa Morosi Kecamatan Morosi dapat dilihat pada Tabel 10.

Tabel 10. Sikap Masyarakat Terhadap Kesempatan Kerja di Desa Morosi Kecamatan Morosi Kabupaten Konawe Tahun 2018.

\begin{tabular}{|c|c|c|c|}
\hline No & $\begin{array}{c}\text { Sikap } \\
\text { Masyarakat } \\
\text { Terhadap } \\
\text { Kesempatan } \\
\text { Kerja }\end{array}$ & $\begin{array}{c}\text { Jumlah } \\
\text { Responden } \\
\text { (Jiwa) }\end{array}$ & $\%$ \\
\hline 1. & Tinggi $\quad(>18)$ & 2 & 4 \\
\hline 2. & Sedang $(14-18)$ & 44 & 90 \\
\hline 3. & Rendah $\quad(<14)$ & 3 & 6 \\
\hline \multicolumn{2}{|c|}{ Jumlah } & 49 & 100 \\
\hline
\end{tabular}

Sumber: Data primer diolah 2018

Tabel 10 menunjukkan bahwa sikap masyarakat Desa Morosi Kecamatan Morosi terhadap aktivitas pabrik smelter yang kaitannya dengan kesempatan kerja yang dimilki oleh masyarakat yang berada pada kategori rendah sebanyak 3 orang (6\%), hal ini dikarenakan masih adanya masyarakat yang masi ragu untuk meningkatkan kemampuannya jika bekerja sebagai karyawan pabrik. Kemudian kategori se- 
dang sebanyak 44 orang $(90 \%)$ sedangkan kategori tinggi sebanyak 2 orang (4\%), hal ini dikarenakan masyarakat lokal yang belum memiliki pekerjaan yang jelas memilih untuk menjadi karyawan pabrik sehingga membuat masyarakat memilih untuk mengembangkan potensi diri dan potensi keluarganya agar dapat bekerja di pabrik smelter tersebut, salah satunya adalah menyekolhkan anaknya untuk dapat bekerja di perusahaan agar perekonomian keluarga meningkat dibandingkan sebeluma adanya pabrik smelter.

Masyarakat menyambut baik keberadaan pabrik smelter yang kaitannya dengan kesempatan kerja yang tersedia semenjak kehadiran pabrik smelter tersebut. Hal ini dapat dilihat dari sikap masyarakat yang memanfaatkan pabrik tersebut untuk bekerja sebagai karyawan, dengan kata lain bahwa semenjak kehadiran pabrik smelter di Desa Morosi Kecamatan Morosi maka tingkat pengguran berkurang secara perlahan dan kesempatan kerja pun semakin bertambah yang dikarenakan kemauan/keinginan masyarakat untuk bekerja di perusahaan. Selain itu dengan adanya pabrik smelter di Desa Morosi membuat masyarakat mengembangkan potensi diri agar mampu bersaing dalam berkerja dan keinginan mengembangkan perekonomian keluarganya semakin meningkat pula, dimana masyarakat Desa Morosi setelah beroprasinya pabrik smelter mulai berkerja sebagai buruh industri dan tidak lagi mencari pekerjaan di luar daerah serta mulai menyekolahkan anak-anaknya ke jenjang yang lebih tinggi agar kedepanya mampu bersaing dengan masyarakat pendatang dalam hal mendapatkan pekerjaan yang lebih baik, yaitu masyarakat lokal hanya mendapatkan pekerjaan sebagai sopir truk, operator alat, satpam dan buruh dalam pabrik smelter tersebut.

\section{c. Peluang Usaha}

Sikap masyarakat terhadap aktivitas pabrik smelter yang kaitannya dengan peluang usaha masyarakat di Desa Morosi Ke- camatan Morosi dapat dilihat pada Tabel 11.

Tabel 11. Sikap Masyarakat Terhadap Peluang Usaha di Desa Morosi Kecamatan Morosi Kabupaten Konawe Tahun 2018

\begin{tabular}{lllcc}
\hline No. & $\begin{array}{c}\text { Sikap Masyarakat } \\
\text { Terhadap Peluang } \\
\text { Usaha }\end{array}$ & $\begin{array}{c}\text { Jumlah } \\
\text { Responden } \\
\text { (Jiwa) }\end{array}$ & \% \\
\hline 1. & Tinggi & $(>19)$ & 1 & 2 \\
\hline 2. & Sedang & $(15-19)$ & 44 & 90 \\
\hline 3. & Rendah & $(<15)$ & 4 & 8 \\
\hline Jumlah & & $\mathbf{4 9}$ & $\mathbf{1 0 0}$ \\
\hline \multicolumn{2}{l}{ Sumber: Data primer diolah 2018}
\end{tabular}

Tabel 11 menunjukkan bahwa sikap masyarakat Desa Morosi Kecamatan Morosi terhadap aktivitas pabrik smelter yang kaitannya dengan peluang usaha yang dimilki oleh masyarakat yang berada pada kategori rendah sebanyak 4 orang $(4,08 \%)$, hal ini dikarenakan masyarakat yang telah memiliki salah satu jenis usaha misalkan berdagang harus bersaing dengan masyarakat pendatang yang membuka jenis usaha yang sama sehingga sebagian masyarakat tidak percaya diri untuk memperluas usaha yang di milikinya. Kemudian kategori sedang sebanyak 44 orang (90\%) sedangkan kategori tinggi sebanyak 1 orang (2\%), hal ini dikarenakan dominan masyarakat yang sebelumnya hanya bekerja sebagai petani namun setelah adanya pabrik smelter membuka berbagai jenis usaha, seperti berdagang dan membuka kios-kios dan menyewakan rumah yang dihuni sebagai kontrakan untuk masyarakat pendatang yang bekerja sebagai karyawan pabrik smelter.

Rata-rata masyarakat menyambut baik terhadap aktifitas pabrik smelter yang kaitannya dengan peluang usaha yang tersedia semenjak kehadiran pabrik smelter tersebut di Desa Morosi Kecamatan Morosi. Hal ini disebabkan karena dengan adanya pabrik smelter telah menambah minat masyarakat untuk memperluas usaha yang di miliki serta sikap masyarakat yang terdorong untuk menciptakan berbagai usaha baru selain usaha pokok yang dige- 
lutinya, seperti masyarakat yang sebelumnya hanya menggantungkan hidupnya dari hasil pertanian kini beralih profesi menjadi karyawan pabrik smelter serta membuka berbagai usaha mikro seperti membangun warung makan, warung sembako, membuka bengkol motor, membangun rumah kost dan lain sebagainya sehingga dapat meningkatkan pendapatannya. Sehingga dapat disimpulkan bahwa dengan adanya pabrik smelter di Desa Morosi Kecamatan Morosi membuka berbagai jenis usaha baru bagi masyarakat sekitar perusahaan.

\section{PENUTUP}

Berdasarkan hasil penelitian yang telah diuraikan pada bagian pembahasan tentang Persepsi Dan Sikap Masyarakat Terhadap Aktivitas Pabrik Smelter di Desa Morosi Kecamatan Morosi Kabupaten Konawe dapat diperoleh kesimpulan bahwa Persepsi masyarakat terhadap keberadaan pabrik smelter khususnya aktivitas perusahaan kaitannya dengan ekonomi yang ditinjau dari aspek pendapatan, kesempatan kerja dan peluang usaha dominan berada pada kategori sedang dan tinggi. Artinya bahwa aktivitas pabrik smelter di Desa Morosi berdampak posistif pada perekonomian masyarakat setempat. Hal ini dikarenakan masyarakata menganggap bahwa sejak adanya perusahaan, penda-patan yang diterima oleh masyarakat me-ningkat serta peluang usaha yang dimilki oleh masyarakat bertambah. Sikap masyarakat terhadap keberadaan pabrik smelter khususnya aktivitas perusahaan kai-tannya dengan ekonomi yang ditinjau dari aspek pendapatan, kesempatan kerja dan peluang usaha dominan berada pada kategori sedang dan tinggi. Artinya bahwa dengan adanya aktivitas pabrik smeter di Desa Morosi Kecamatan Morosi, masyarakat banyak yang beralih profesi menjadi karyawan perusahaan serta membuka berbagai jenis usaha mikro sehingga menaikkan pendapatan masyarakat khususnya masyarakat yang bermukim di sekitar perusahaan khususnya masyarakat di Desa Morosi Kecamatan Morosi.

\section{DAFTAR PUSTAKA}

Arikunto, S. (2016). Prosedur Penelitian Suatu Pendekatan Praktik. Jakarta: Rineka Cipta.

Azwar, S. (2009). Sikap Manusia Edisi II. Yogyakarta: Pustaka Pelajc

Azwar, S. (2007). Sikap Manusia Teori dan. Pengukurannya. Jakarta: Pustaka Pelajar.

Bintarto, H.R, (1988). Interaksi Desa Kota dan Permasalahannya. Jakarta: Ghalia Indonesia.

BPS (2017). Kabupaten Konawe Dalam Angka 2017. BPS Kabupaten Konawe. Kendari: CV. Metro Graphia Kendari.

Herman, Danny Z. (2005). Kegiatan Pemantauan dan Evaluasi Konservasi Sumber Daya Mineral daerah Bangka Tengah, Provinsi Bangka Belitung. Jakarta: Hasil Kegiatan Subdit Konservasi.

Kementerian ESDM. (2015). Dampak Pembangunan Smelter di Kawasan Ekonomi Khusus Provinsi Sulawesi Tenggara. Jakarta: Pusat Data dan Teknologi Informasi Kementerian Energi dan Sumber Daya Mineral.

Kartodihardjo, H., Safitri, M., Ivalerina, F., Khan A., \& Tjendronegoro, S.M.P., 2005, Di Bawah Satu Payung Pengelolaan Sumber Daya Alam, Suara Bebas, Jakarta.

Raden I., Pulungan, MS., Dahlan, M., \& Thamrin. (2010). Kajian Dampak Penambangan Batu Bara Terhadap Kondisi Sosial Ekonomi dan Lingkungan Kabupaten Kutai Kartanegara. Jakarta: Badan pengembang Kemaritiman Dalam Negeri.

Republik Indonesia. (2003). UndangUndang Nomor 20 Tahun 2003 tentang Sistem Pendidikan Nasional. Lembaran Negara Republik Indonesia 
Nomor 4301. Jakarta: Sekretariat Negara Republik Indonesia.

Republik Indonesia. (2004). UndangUndang Nomor 32 Tahun 2004 tentang Pemerintah Daerah. Lembaran Negara RI Nomor 4437. Jakarta: Sekretariat Negara Republik Indonesia..

Republik Indonesia. (2009). Undangundang Pertambangan Nomor 4 Tahun 2009 tentang Pertambangan Mineral dan Batubara. Lembaran Negara RI Tahun 2009, Nomor 4959. Jakarta: Sekretariat Negara Republik Indonesia.

Soeharjo, A. dan D. Patong. (1984). SendiSendi Pokok Ilmu Usahatani. Ujung Pandang: Lembaga Penerbit Universitas Hasanuddin.

Sugiyono. (2009). Metode Penelitian Kuantitatif, Kualitatif dan R\&D. Bandung: CV. Alfabeta. Bandung. 